\title{
Pengaruh Efektivitas Pembelajaran Daring Terhadap Pemahaman Mahasiswa Akuntansi Pada Mata Kuliah Auditing (Studi Kasus Mahasiswa Akuntansi Universitas Potensi Utama)
}

The Effect of Online Learning Effectiveness on Accounting Students' Understanding of Auditing Courses (Case Study of Accounting Students in Universitas Potensi Utama)

\section{Siti Aisyah}

Fakultas Ekonomi dan Bisnis, Program Studi Akuntansi, Univesitas Potensi Utama,Jl. K.L.Yos Sudarso, Tj.Mulia,Medan Deli, Kota Medan-20241 Telp (061)6640525

Email: aisyah10041993@gmail.com

\begin{abstract}
ABSTRAK
Tujuan penelitian ini adalah untuk mengetahui pengaruh efektivitas pembelajaran daring terhadap pemahaman mahasiswa akuntansi pada mata kuliah auditing. Adapun jenis dan sumber data yang digunakan adalah data primer berupa observasi dan informasi yang langsung diperoleh dari mahasiswa mengenai permasalahan yang terjadi. Untuk data sekunder, peneliti memperolehnya denganmeng gunakan angket atau kuesioner yang disebar kemudian diolah dengan menggunakan SPSS. Teknik analisis datayang digunakan adalah dengan melakukan uji asumsi klasik, regresi linier berganda, uji hipotesis dan uji determinasi.Proses daring yang masih awam dikalangan masyarakat indonesia dalam pelaksanaannya benar - benar sangat menguras emosi, mental, fisik dan materi. Kita yang masih banyak belumfaham dan tidak begitu mengerti menggunakan teknologi dalam pembelajaran daring pasti sangat sulit mengikuti kegiatan belajar ini. Keterbatasan materi dalam membeli kuota, belum lagi akses internet yang tidak stabil, para siswa maupun mahasiswa yang tinggal dipelosok dan belum terlalu terjangkau sinyal sangatlah kesulitan mengikuti proses belajar mengajar ini. Berdasarkan hasil kuesioner yang peneliti sebarkan, maka di dapatkanlah hasil penelitian bahwasannya efektivitas pembelajaran daring berpengaruh signifikan terhadap pemahaman mahasiswa akuntansi pada mata kuliah auditing, dan dari hasil uji $R$ diketahui besaran nilai pengaruhnya sebesar $77,1 \%$.
\end{abstract}

Kata Kunci : efektivitas pembelajaran daring, pemahaman mahasiswa, auditing

\section{ABSTRACT}

The purpose of this study was to determine the effect of the effectiveness of online learning on accounting students' understanding of auditing courses. The types and sources of data used are primary data in the form of observations and information directly obtained from students regarding the problems that occur. For secondary data, researchers obtained it by using a questionnaire or a questionnaire which was distributed and then processed using SPSS. The data analysis technique used is classical assumption test, multiple linear regression, hypothesis testing and determination test. The online process which is still common among Indonesian people in its implementation is really very draining emotionally, mentally, physically and materially. Many of us who still don't understand and don't really understand using technology in online learning must be very difficult to follow this learning activity. Material limitations in purchasing quotas, not to mention unstable internet access, students and students who live in remote areas and have not yet reached the signal are very difficult to follow this teaching and learning process. Based on the results of the questionnaires that the researchers distributed, the results of the study showed that the effectiveness of online learning had a significant effect on the understanding of accounting students in auditing courses, and from the results of the R test, it was found that the magnitude of the effect was $77.1 \%$.

Keywords : effectiveness of online learning, student understanding, auditing 


\section{PENDAHULUAN}

Para mahasiswa merupakan aset penting dan paling utama yang terpentingdalam dunia pendidikan dan di sebuah universitas. Dimasa pandemi covid-19 ini, pemerintah mengeluarkan keputusan yang menyuruh para mahasiswa untuk melakukan proses pembelajaran yang biasanya tatap muka menjadi secara daring atau menggunakan media elektronik. Selama proses pelaksanaan perkuliahan secara daring, mahasiswa diwajibkan untuk menggunakan dan menguasai penggunaan berbagai media pembelajaran daring yang tpastinya disesuaikan dengan mata kuliah yang diikuti. Adapun jenis- jenis penggunaan media pembelajaran daring, misalnya: google meet, google classroom, whatsapp group, video tutorial, video conference, e-learnuing atau media lainnya yang relevan dan layak untuk dijadikan sebagai media pembelajaran daring. Penelitian ini bertujuan untuk mengetahui pengaruh efektivitas media pembelajaran daring terhadap pemahaman mahasiswa akuntansi pada mata kuliah auditingi. Tidak dipungkiri bahwasannya Pandemi covid-19 yang mewabah diseluruh dunia telah menganggu jalannya kelancaran aktivitas manusia diberbagai sektor, baik sektor ekonomi, politik, wisata, bahkan pendidikan. Kehidupan normal yang sebelumnya dijalani juga harus berubah, dimana menjadi new normal yang baru dan harus mampu menerapkan protokol kesehatan agar manusia tetap bisa beraktivitas meskipun pandemi belum berakhir. Inilah yang sekarang sedang dirasakan oleh sektor pendidikan diseluruh dunia. Pandemi covid-19 ini telah merubah tatanan pelaksanaan pendidikan yang sehari-harinya bertatap muka, lebih leluasa dalam berinteraksi dan belajar menjadi lebih terbatas dan menggunakan media daring saja. Tentulah media daring yang dicanangkan oleh pemerintah semata-mata untuk mengurangi jumlah manusia yang terkena covid-19 dan berharap agar rantai covid bisa segera berakhir. Namun, tidak dapat dihindari bahwa kenyataannya, pembelajaran yang dilakukan secara daring tidak serta merta berjalan dengan mulus dan sesuai harapan. Tentu banyak kendala yang dhadapi oleh pemerintah, guru, dosen, siswa, mahasiswa, dan praktisi mengajar lainnya. Proses daring yang masih awam dikalangan masyarakat indonesia dalam pelaksanaannya benar - benar sangat menguras emosi, mental, fisik dan materi. Kita yang masih banyak belum faham dan tidak begitu mengerti menggunakan teknologi dalam pembelajaran daring pasti sangat sulit mengikuti kegiatan belajar ini. Keterbatasan materi dalam membeli kuota, belum lagi akses internet yang tidak stabil, para siswa maupun mahasiswa yang tinggal dipelosok dan belum terlalu terjangkau sinyal sangatlah kesulitan mengikuti proses belajar mengajar ini. Fenomena ini jugalah yang terjadi pada mahasiswa akuntansi di universitas potensi utama. Selama pandemi ini terjadi, tentulah pihak universitas potensi utama juga mengikuti arahan pemerintah untuk mengadakan perkuliahan secara daring. Namun, seperti yang sudah peneliti jelaskan diawal bahwasannya proses pembelajaran ini tidaklah berjalan mulus diawal, bahkan hingga sekarang. Apalagi untuk mata kuliah auditing yang pastinya bukan hanya teori saja, ada banyak kasus yang harus diselesaikan, dan dilamnya ada banyak perhitungan. Tidak mudah bagi para mahasiswa untuk menyerap apa yang dijelaskan oleh dosen secara virtual. Selain itu momen untuk bertanya juga sangat terbatas karena akses internet yang juga terbata. Sehingga lebih banyak mahasiswa yang hanya sekedar mengikuti perkuliahan, tetapi banyak tidak fahamnya terhadpa materi yang diajarkan. Banyak sekali yang harus dibenahi disegala aspeknya agar semua pihak yang terlibat dan ikut proses belajar mengajar daring siap secara mental, fisik, dan materi untuk mengikuti proses pemberlajaran ini.

\section{A. Tujuan Penelitian}

Adapun tujuan penelitian yang ingin dicapai oleh peneliti adalah sebagai berikut:

1) Untuk mengetahui dan menganalisis pengaruh efektivias pembelajaran daring terhadap pemahaman mahasiswa akuntansi pada mata kuliah auditing

2) Untuk mengetahui apakah variabel efektivitas pembelajaran daring memiliki pengaruh yang signifikan terhadap pemahaman mahasiswa akuntansi pada mata kuliah auditing 


\section{B. Rumusan Masalah}

Adapun yang menjadi rumusna masalah dalam penelitian ini adalah sebagai berikut :

1) Apakah pembelajaran daring berpengaruh signifikan terhadap pemahaman mahasiswa akuntansi pada mata kuliah auditing?

2) Apakah pembelajaran daring efektif dilakukan untuk meningkatkan pemahaman mahasiswa akuntansi pada mata kuliah auditing?

\section{LANDASAN TEORI}

\section{A. Pembelajaran Daring}

Didalam dunia perkuliahan, mahasiswa merupakan aset utama yang menjadi ujung tombak untuk mencapai visi dan misi dari sebuah universitas. Visi dan misi yang ingin dicapai suatu universitas pastilah bertujuan untuk meningkatkan mutu pendidikan secara global guna terciptanya para generasi bangsa yang cerdas dan berdaya saing. Seiring dengan pesatnya kemajuan dan perkembangan ilmu pengetahuan dan teknologi diseluruh dunia, banyak perubahan yang terjadi di dunia pendidikan maupun teknologi dan sains.

Banyak sekali faktor-faktor yang mempengaruhi kemajuan dan perkembangan pendidikan di masa sekarang dan akan mendatang, di antaranya adalah perkembangan teknologi informasi yang sangat pesat. Pendidikan dan proses pembelajaran yang berbasis pada kompetensi merupakan contoh dari hasil perubahan dengan tujuan meningkatkan kualitas pendidikan dan pembelajaran. Terlebih lagi pada masa pandemi covid-19 yang sedang melanda seluruh dunia ini, yang menyebabkan adanya keputusan pemerintah yang mengharuskan atau mewajibkan para mahasiswa dan dosen untuk melakukan proses pembelajaran secara daring demi memutus rantai covid-19 dan agar mahasiswa tetap aktif, kreatif, serta produktif dalam pendidikan, sehingga media sosial dan teknologi yang tersedia dapat dimanfaatkan sebaik-baiknya untuk mendukung proses pembelajaran secara daring.

Aktivitas pembelajaran secara daring yang sekarang sedang dijalankan oleh para praktisi mengajar di Indonesia memang bukanlah hal yang mudah. Ini hal yang baru bagi kita semua. Banyak kendala yang dihadapi, dan banyak hal yang masih harus dipelajari para praktisi ajar dan mahasiswa yang di ajar agar mampu memaksimalkan proses pembelajan secara daring ini. Berikut pendapat para ahli mengenai arti dari pembelajaran daring:

1) Menurut Rustaman(2020.558), pembelajaran daring merupakan aktivitas pembelajaran yang dilakukan secara online(virtual) dengan menggunakan aplikaasi internet atau jejaringan sosial lainnya guna mencapai tujuan pembelajaran.

2) Menurut Bilfaqih dan Qomarudin(2015:1) model pembelajaran daring adalah model pembelajaran yang dilaksanakan dengan menggunakan jaringan internet untuk menjangkau kelompok belajar yang lebih luas dan tidak terbatas

3) Sedangkan menurut Romli (2021:34) media daring adalah segala jenis aktivitas, komunikasi, dan media baik foto, dokumen, video yang hanya bisa dikases menggunakan internet.

Berdasarkan pengertian beberapa ahli diatas, maka peneliti menyimpulkan bahwasannya benar bahwa proses pembelajaran daring adalah proses pembelajaran yang sangat bergantung dengan media internet dalam pelaksanaannya, yang mampu menyampaikan berbagai informasi baik foto, dokumen, video dan lainnya kepada para mahasiswa demi tercapainya tujuan pembelajaran. 


\section{B. Indikator pengukur Efektivitas Pembalajaran daring}

Setiap akhir proses pembelajaran, pastilah seorang dosen akan melakukan evaluasi terhadap hasil belajar dan mengajar yang ia lakukan, untuk melihat apakah tujuan pembelajaran tercapai atau tidak. Disinilah keefektifan media daring sangat diharapkan mampu untuk mencapai tujuan pembelajaran tersebut. Yusuf (2017) mengatakan bahwasannya ada 5 indikator untuk mengukur keberhasilan efektivitas belajar, yaitu:

1. Proses komunikasi yang terjadi antara dosen dan mahasiswa

2. Pelaksanaan pembelajaran yang dilakukan secara daring

3. Respon peserta didik (mahasiswa) dalam mengikuti proses pembelajaran secara daring

4. Aktivitas belajar mahasiswa selama proses pembelajaran

5. Hasil belajar yang dievaluasi setiap akhir pertemuan

Dalam praktiknya, proses daring ini bisa menggunakan banyak aplikasi sebagai media pembelajaranannya, seperti zoom, google meet, google classroom, e-learning, dan sebagainya. Jadi para mahasiswa dan dosen harus semaksimal mungkin menggunakan berbagai aplikasi pembelajaran daring, guna mencapai tujuan pembelajaran yang diinginkan.

\section{Pengertian Pemahaman Mahasiswa}

Kata dasar dari pemahaman adalah faham, yang artinya tanggap, mengerti, mengetahui, dan memahami sesuatu yang telah dia dengar dan lihat. Begitu pula dengan mahasiswa yang mempelajari mata kuliah auditing. Sebagai dosen, tentu sangat berharap para mahasiswanya mampu memahami materi yang telah disampaikan selama daring.

Ada beberapa ahli yang mengemukakan pendapatnya mengenai pengertian pemahaman, yaitu:

1) Menurut Ngalim Purwanto (2010:44) pemahaman adalah kemampuan testee atau para mahasiswa mengerti atau memahami informasi yang di dapatkannya baik secara konsep dan aktualisasinya.

2) Sadirman juga mengatakan bahwa pemahaman adalah kemmapuan untuk mengerti akan sesuatu dengan menggunakan fikirannya.

3) Vivi utari, Ahmad fauzan dan Media Rosha juga mengemukakan bahwasannya yang dimaksud dengan pemahaman adalah kemampuan siswa untuk menyerap, menerjemahkan, menafsirkan, dan menyimpulkan suatu konsep pembelajaran yang telah ia pelajari sehingga para siswa tidak hanya mengerti secara teori dan hafalan saja, namun mampu untuk menganalisisnya pada kehidupan sehari-hari.

Dari semua pendapat para ahli di atas, maka peneliti menarik kesimpulan bahwasannya yang dimaksud dengan pemahaman adalah mahasiswa bukan hanya mampu mengerti secara konsep dan teori terhadap materi yang ia pelajari, namun mahasiswa juga harus mampu menganalisis, mengaplikasikan ilmu yang ia dapat pada fakta kehidupan sehari-hari.

Begitu juga halnya dengan materi kuliah auditing, dimana peneliti sebagaidosen pengampu mata kuliah audit berharap mahasiswa bukan hanya mampu memahami secara teori, sebatas menghafal dan menjawab berdasarkan informasi yang ia dapat dari internet saja, namun harus mampu menganalisis informasi yang didapat, di susun secara rapi sesuai urutan jawaban berdasarkan konsep, lalu menjelaskannya dengan menggunakan bahasan sendiri. Sehingga dengan demikian, tanpa menghafal maka mahasiswa sudah mampu mengerti dan mampu menjelaskan materi yang disampaikan dengan bahasa pemahamannya sendiri, namun tetap tidak keluar jalur dari konsep dasar materi tersebut. 


\section{Indikator Pengukur Pemahaman Mahasiswa}

Menurut Wina Sanjaya (2008:45) bahwasannya ada 3 indikator yang dapat menjadi tolok ukur pemahaman mahasiswa, yaitu :

1) Menerjemahkan, yang artinya adalah mahasiswa diharapkan mampu menerjemahkan konsep yang telah ia pelajari dengan simbol atau kode yang ia ciptakan dnegan bahasanya sendiri, sehingga ia tidak perlu menghafal, namun hanya sekedar mengingat inti atau hal penting dari materi yang ia pelajari, yang kemudia dapat dijelaskan dengan bahasa sendiri.

2) Menginterpretasikan/ Menafsirkan, yangg artinya mahasiswa mampu menggambarkan secara jelas dan rinci apa yang telah dipelajari dengan gaya bahasanya sendiri.

3) Mengekstrapolasi, yang artinya pada tahap ini mahasiswa diharapkan mampu untuk kreatif dan berkembang mengemukakan ide - ide yang dapat memperluas ranah masalah dari materi yang dipelajari. Dengan kata lain, mahasiswa mampu menganalisis dan mengembangkan masalah yang ada dengan pemikirannya sendiri

\section{E. Auditing}

Secara umum auditing merupakan suatu proses untuk memperoleh, mengolah dan mengevaluasi bukti atau temuan secara objektif, independen dan andal mengenai suatu permasalahan dan pernyataan tentang kegiatan ekonomi sebuah perusahaan yang tujuannya adalah untuk menghasilkan laporan audit yang nantinya informasi hasil audit tersebut akan digunakan oleh pihak - pihak yang berkepentingan seperti pemlik perusahaan, karyawan, pemerintah, investor, dan sebagainya.

Menurut Mulyadi (2010:9) Auditing merupakan suatu proses yang bersifat sistematik atau terencana yang dilakukan untuk memperoleh ,menganalisis, dan mengevaluasi bukti secara objektif atau fakta.

Menurut Haryono Jusup (2011: 11) Auditing merupakan suatu proses sistematis atau berurut yang dilakukan untuk mendapatkan informasi atau kebenaran mengenai suatu kejadian ekonomi dan mengevaluasi bukti yang berhubungan dengan asersi tserta tindakan-tindakan dan kejadian kejadian ekonomi secara objektif atau faktual guna memberikan informasi audit yang andal bagi para pengguna informasi.

Menurut Sukrisno Agoes (2012:4) Auditing adalah suatu kegiatan pemeriksaan transaksi atau kejadian ekonomi yang dilakukan secara kritis dan sistematis oleh pihak yang ekspert dan independen dibidang audit. Audit ini dilakukan terhadap laporan keuangan perusahaan yang telah disusun oleh pihak manajemen perusahaan, beserta temuan -temuan berupa catatan-catatan pembukuan dan bukti-bukti transaksi pendukungnya, dengan tujuan untuk dapat memberikan pendapat atau hasil audit mengenai kewajaran atau ketidakwajaran laporan keuangan tersebut.

Dari beberapa pendapat para ahli di atas maka peneliti menyimpulkan bahwa auditing merupakan suatu proses kegiatan yang disusun secara sistematis, yang bertujuan untuk menilai, menganalisis, mengevaluasi hasil temuan atas kegiatan ekonomi sebuah perusahaan, untuk nantinya dikeluarkan asersi atau pernyataan audit yang biasa dikenal dengan laporan auditor menyangkut kewajaran laporan yang diperiksa oleh auditor.

\section{F. Tujuan Auditing}

Menurut Standar Akuntan Publik Indonesia (2011:110:1) tujuan auditing adalah Untuk memberikan pernyataan audit atas kewajaran suatu hal yang bersifat material, baik itu posisi keuangan perusahaan, arus kasnya, dan laporan lainnya yang nantinya akan dievaluasi apakah sudah sesuai prinsip akuntansi yang berlaku umum atau tidak. Jika laporan keuangan yang diperiksa sudah sesuai standar dan sesuai transaksi yang terjadi maka pihak auditor akan 
memebrikan penryataan audit berupa kewajaran laporan keuangan atau sebaliknya.

Menurut Tuanakotta (2014:84) tujuan audit adalah untuk meningkatkan kepercayaan para pengguna informasi audit terhadap perusahaan yang diaudit. Dalam arti lain, audit dilakukan untuk menjaga kredibilitas perusahaan, yang didukung oleh pemberian opini yang baik dan wajar oleh auditor.

Dari beberapa pernyataan para ahli diatas, maka dapat disimpulkan bahwa tujuan dilakukannya audit adalah untuk menilai dan mengevaluasi laporan keuangan perusahaan yang dibuat oleh pihak manajemen perusahaan, yang nantinya akan diperiksa dan dinilai kewajarannya oleh auditor.

\section{METODOLOGI PENELITIAN}

\section{A. Jenis Data}

Adapun jenis data yang diperoleh peneulis dalam penelitian ini adalah sebagai berikut :

\section{1) Data Primer}

Merupakan data yang diperoleh secara langsung oleh penulis dari sumber datanya. Data primer disebut juga sebagai data asli atau data baru terkini. Untuk mendapatkan data primer, penulis harus mengumpulkannya secara langsung. Adapun sumber data primer dari penelitian ini adalah para mahasiswa akuntansi pagi dan malam semester 4 yang mengambil mata kuliah auditing. Jumlah populasinya adalah 86 orang, dan jumlah sampelnya sebanyak 50 orang dengan menggunakan metode random sampling.

2) Data Sekunder Data yang penulis peroleh penulis dari berbagai sumber yang telah ada. Data sekunder dapat diperoleh dari berbagai sumber seperti buku, jurnal, informasi dari pihak kampus, maupun internet.

\section{B. Metode Pengumpulan Data}

Dalam kegiatan penelitian ini, data dan informasi dikumpulkan dengan menggunakan beberapa teknik pengumpulan data, yaitu:

a. Observasi

Observasi yang dilakukan oleh penulis adalah dengan mengamati dan menganalis is permasalahan yang terjadi pada mahasiswa yang mempelajari mata kuliah auditing di universitas potensi utama.

b. Angket

Adapun tujuan penggunaan angket adalah untuk menghitung nilai dari kuesioner yang disebarkan oleh peneliti, untuk kemudia diolah datanya menggunakan spss. Nilai yang terdapat pada kuesioner menggunakan skala likert 1 sampai 5.

\section{Metode Analisis Data}

Metode analisis yang digunakan oleh penulis adalah metode analisis kuantitatif, variabel penelitian yang dteliti pada penelitian ini hanya 1 variabel $\mathrm{X}$ dan 1 variabel $\mathrm{Y}$, sehingga hanya perlu menganalisis atau menguji data berupa:

1) uji validitas dan reliabilitas.

2) uji asumsi klasik yang terdiri dari uji normalitas dan heteroskedastisitas.

3) uji regresi linier berganda 
4) uji hipotesis yaitu uji-t

5) Uji determinasi

\section{Waktu Penelitian}

Penelitian ini dilaksanakan pada bulan agustus 2021 sampai bulan september 2021 di universitas potensi utama Medan

\section{HASIL DAN PEMBAHASAN}

Dalam setiap proses pembelajaran, para mahasiswa diharapkan dapat mengerti dan memahami materi pembelajaran dengan baik. Pemahaman dalam proses belajar berarti mahasiswa bisa menagkap, menyimak, dan memahami semua materi yang telah dijelaskan oleh dosen selama proses pembelajaran. Tanpa adanya pemahaman pada materi yang telah diajarkan, maka akan mempengaruhi tingkat pengetahuan,keterampilan,dan sikap mahasiswa tersebut. Selanjutnya, pemahaman pada para mahasiswa ini dibagi ke dalam tiga kategori, yaitu: (a) tingkat pertama atau tingka yangt terendah, yaitu pemahaman terjemahan, dalam arti memahami materi secara terjemahan atau baku ; (b) tingkat kedua adalah pemahaman berupa penafsiran, yaitu menghubungkan dan mengaitkan bagian-bagian terdahulu dengan yang diketahui sekarang atau berikutnya, atau dengan kata lain menghubungkan beberapa bagian dari grafik dengan kejadian, membedakanyang pokok dan yang bukan pokok; dan (c) pemahaman tingkat ketiga atau pemahaman tingkat tertinggi, yakni pemahaman ekstrapolasi .Berdasarkan uraian tersebut, dapat diketahui bahwa pemahaman merupakan hal terpenting dalam pembelajaran karena sebagai bentuk pernyataan hasil belajar. Maka, untuk meningkatkan pemahaman diperlukan proses belajar yang baik dan benar. Pemahaman mahasiswa akan dapat berkembang bila proses pembelajaran terlaksana dengan efektif dan efisien. Dengan demikian, dilakukanlah penelitian ini yang bertujuan untuk mengetahui hubungan media pembelajaran daring terhadap peningkatan pemahaman belajar mahasiswa akuntansi pada mata kuliah auditing di Universitas Potensi Utama. Selain itu, penelitian ini bisa menjadi salah satu rekomendasi bagi pengajar dalam pemilihan penggunaan media pembelajaran yang bisa dipahami oleh mahasiswa selama pembelajaran dimasa pandemi saat ini.

Sebelum menyebarkan kuesinoer kepada para sampel penelitian, terlebih dahulu peneliti melakukan uji validitas dan realibilitas. Setelah di dapatkan hasil bahwa kuesioner yang disebar valid dan reliabel, barulah kuesioner tersebut diberikan kepada sampel penelitian. Berdasarkan data kuesioner yang peneliti olah, maka dilakukan uji asumsi klasik, uji analisis data dengan menggunakan analisis regresi linier berganda, dan uji hipotesis. Berikut hasil uji asumsi klasik dari penelitian ini:

\section{A. Uji Asumsi Klasik}

Pengujian asumsi klasik yang dimaksudkan untuk memastikan apakah model regresi linier berganda dapat digunakan atau tidak. Apabila uji asumsi klasik telah terpenuhi,maka alat uji statistic linier berganda dapat dipergunakan.

\section{1) Uji Normalitas}

Menurut Ghozali (2009) uji normalitas dapat dilakukan dnegan menggunakan tabel kolmorgorov-smirnov test dengan tingkat signifikansi 0,05 , jika signifikan $\leq 0,05$ maka data tidak berdistribusi normal, dan sebaliknya Untuk menguji kenormalan dat apada penelitian ini, maka peneliti melihat hasil melalui analisa grafik dan statistik yang dihasilkan melalui perhitungan regresi dengan SPSS, berupa tabel kolmorgorov-smirnov dan P- P Plot. 


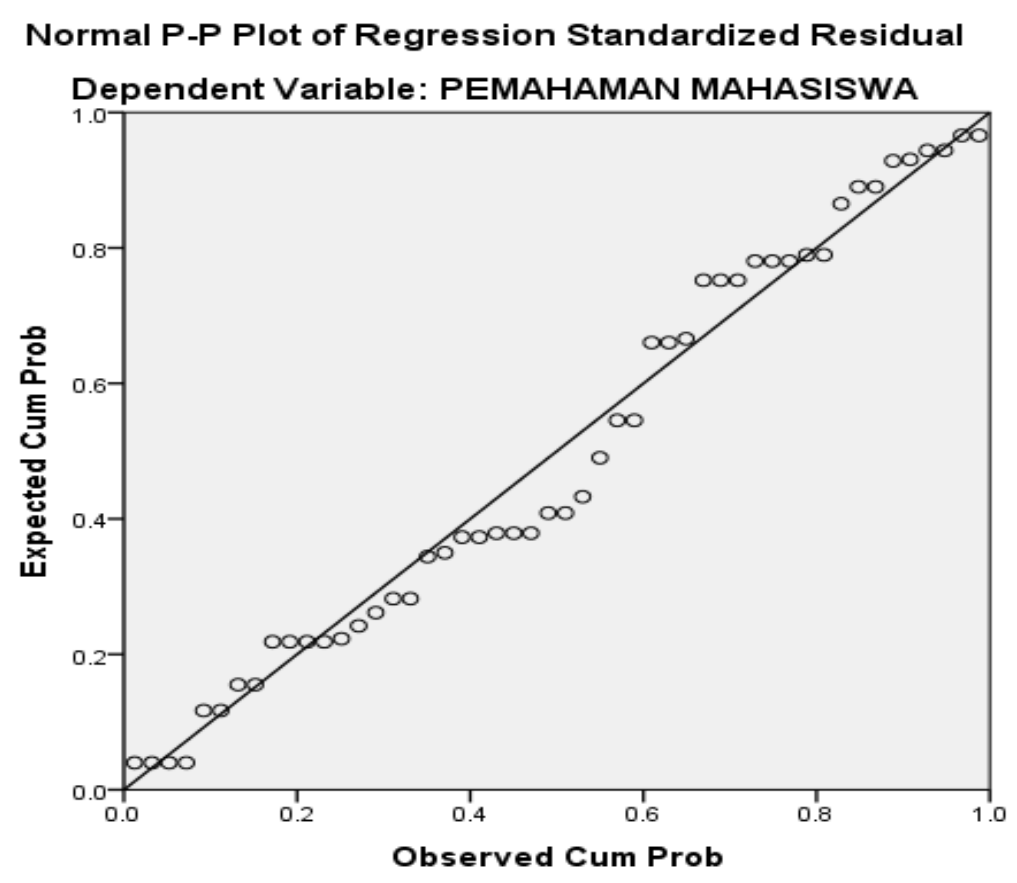

Gambar 1. Uji Normalitas P-P Plot

Dapat dilihat dari gambar 4.1 bahwa pada grafik normal P-P plot, terlihat titik-titik tersebar disekitar garis diagonal atau tidak terlalu jauh dari garis diagonal, serta arah penyebarannya mengikuti garis diagonal, sehingga dapat dinyatakan bahwa data berdistribusi normal.

Tabel 1. Uji Kolmorgorov-smirnov

One-Sample Kolmogorov-Smirnov Test

\begin{tabular}{|ll|r|}
\hline & & Unstandardized Residual \\
\hline $\mathrm{N}$ & & 50 \\
Normal Parameters ${ }^{\mathrm{a}, \mathrm{b}}$ & Mean & $0 \mathrm{E}-7$ \\
& Std. Deviation & 2.74259242 \\
& Absolute & .112 \\
Most Extreme Differences & Positive & .112 \\
& Negative & -.094 \\
Kolmogorov-Smirnov Z & & .794 \\
Asymp. Sig. (2-tailed) & & .553 \\
\hline
\end{tabular}

a. Test distribution is Normal.

b. Calculated from data.

Berdasarkan hasil uji K-S pada tabel diatas, maka dapat dilihat bahwa besarnya nilai K-S adalah 0,794 dan signifikan pada 0,553 , yang artinya bahwa data residual terdistribusi secara normal karena $>0,05$. 
2) Uji Heteroskedastisitas

Uji heteroskedastisitas pada penelitian ini dilakukan dengan menggunakan Grafik Plot dengan nilai prediksi variabel dependen yaitu Standardized Predicted Value (ZPRED) dengan residualnya Studentized Residual (SRESID). Jika ada pola tertentu dari titik - titik yang dihasilkan, maka telah terjadi heteroskedastisitas, dan sebaliknya. Maka data yang baik adalah yang tidak memiliki pola tertentu atau tidak terjadi heteroskedastisitas.

Hasil pengujian heteroskedastisitas data dalam peneliian inni menggunakan SPSS V20 dengan mengamati pola yang terdapat pada scatterplots. Hasilnya dapat dilihat pada gambar 2 berikut ini :

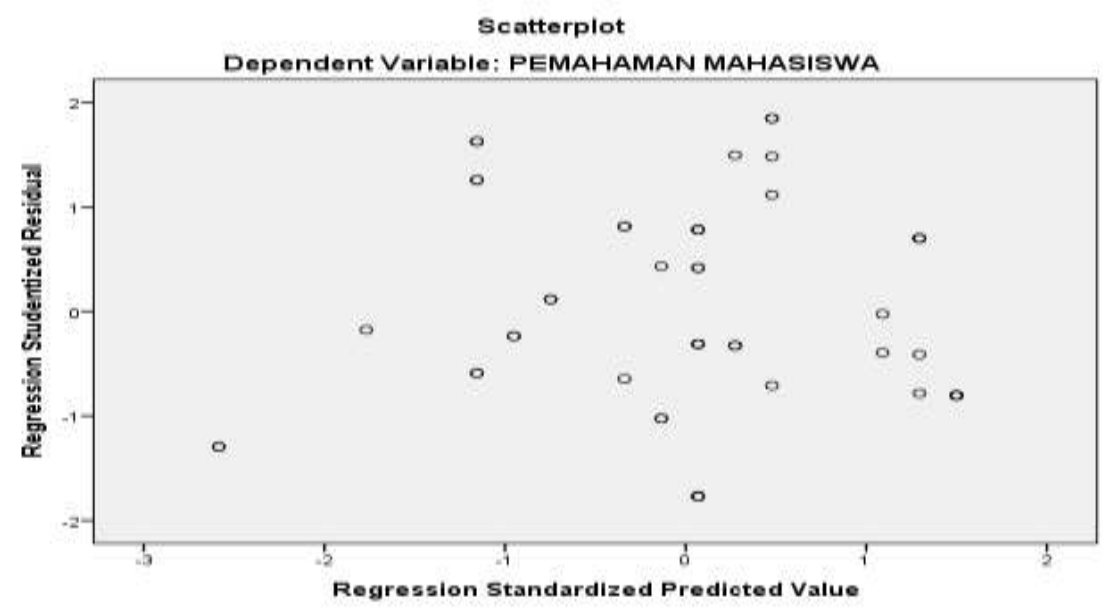

Gambar 2. Hasil Uji Heteroskedastisitas

Berdasarkan gambar 2 diatas, dapat dilihat bahwasannya titik-titik menyebar secara acak (random) atau tidak membentuk pola tertentu, serta tersebar diatas maupun dibawah angka 0 pada sumbu Y. Sehingga dapat disimpulkan bahwa tidak terjadi heteroskedastisitas pada model regresi, sehingga model regresi layak dipakai.

\section{B. Analisis Regresi Linier Berganda}

Analisis ini digunakan untuk mengetahui pengaruh Efektivitas Pembalajaran daring Terhadap Pemahaman Mahasiswa Akuntansi Pada Mata Kuliah Auditing.. Hasil pengolahan data pada analisis regresi linier berganda ini dilakukan dengan bantuan komputer program SPSS versi 20 , dan berikut hasilnya:

Tabel 2. Uji Analisis Regresi Linier berganda

\section{Coefficients $^{\mathrm{a}}$}

\begin{tabular}{|c|c|c|c|c|c|c|}
\hline \multirow{2}{*}{\multicolumn{2}{|c|}{ Model }} & \multicolumn{2}{|c|}{$\begin{array}{l}\text { Unstandardized } \\
\text { Coefficients }\end{array}$} & \multirow{2}{*}{$\begin{array}{c}\text { Standardize } \\
\text { d } \\
\text { Coefficients } \\
\text { Beta }\end{array}$} & \multirow[t]{2}{*}{$\mathrm{t}$} & \multirow[t]{2}{*}{ Sig. } \\
\hline & & B & Std. Error & & & \\
\hline \multirow{4}{*}{1} & (Constant) & 5.828 & 1.952 & & 2.985 & .004 \\
\hline & EFEKTIVITAS & & & & & \\
\hline & PEMBELAJARAN & 1.043 & .081 & .881 & 12.901 & .000 \\
\hline & DARING & & & & & \\
\hline
\end{tabular}

a. Dependent Variable: PEMAHAMAN MAHASISWA 
Berdasarkan tabel 2 pada kolom Unstandardized Coefisients di atas, maka diperoleh model persamaan regresi linier berganda yaitu:

$$
\begin{gathered}
\mathrm{Y}=\mathrm{a}+\mathrm{b} 1 \mathrm{X} 1+\mathrm{e} \\
\mathrm{Y}=5,828+1.043+\mathrm{e}
\end{gathered}
$$

Dimana:

$\mathrm{Y} \quad=$ Pemahaman Mahasiswa

$\mathrm{X} 1=$ Efektivitas Pembalajaran daring

Dari persamaan regrasi linier sederhana di atas, maka dapat diinterprestasikan beberapa hal, antara lain:

1. Nilai ini menyatakan jika variabel independen dianggap 0, maka nilai Pemahaman Mahasiswa adalah sebesar 5.828.

2. Variabel eEfektivitas Pembalajaran daring memiliki nilai koefisien regresi yaitu 1,042. Nilai koefisien yang positif ini menunjukan bahwa setiap kenaikan Efektivitas Pembalajaran daring sebesar $1 \%$, maka nilai pemahaman mahasiswa akan mengalami kenaikan sebesar 1,042 , dan sebaliknya.

\section{Uji Hipotesis (Uji-t)}

Pengujian hipotesis dilakukan untuk mengetahui pengaruh dan tingkat signifikan masing-masing variabel independen terhadap variabel dependen atau dengan kata lain untuk menguji pengaruh variabel independen terhadap variabel dependen secara parsial dan simultan. Dalam hal ini adapun kriteria yang digunakan adalah sebagai berikut:

a. Ho diterima dan Ha ditolak apabila thitung < t tabel dan signifikan > 0,05, atau dapat diartikan bahwa tidak ada pengaruh media daring terhadap pemahaman mahasiswa akuntansi pada mata kuliah auditing.

b. Ha diterima dan Ho ditolak apabilah thitung $>\mathrm{t}$ tabel dan signifikan $<0,05$ dengan kata lain Ha diterima maka terdapat pengaruh Efektivitas Pembalajaran daring terhadap pemahaman mahasiswa pada mata kuliah auditing.

Uji $t$ dilakukan untuk menguji pengaruh variabel bebas (independent) terhadap variabel tidak bebas (dependent) secara terpisah atau sendiri-sendiri (parsial). Berdasarkan hasil analisis , dapat diketahui hasil uji t seperti tampak pada tabel 4.4 berikut:

Tabel 3. Hasil Uji-t

\begin{tabular}{|c|c|c|c|c|c|c|}
\hline \multirow{2}{*}{\multicolumn{2}{|c|}{ Model }} & \multicolumn{2}{|c|}{$\begin{array}{c}\text { Unstandardized } \\
\text { Coefficients }\end{array}$} & \multirow{2}{*}{$\begin{array}{c}\begin{array}{c}\text { Standardize } \\
\text { d } \\
\text { Coefficients }\end{array} \\
\text { Beta }\end{array}$} & \multirow[t]{2}{*}{$\mathrm{t}$} & \multirow[t]{2}{*}{ Sig. } \\
\hline & & B & Std. Error & & & \\
\hline \multirow{4}{*}{1} & (Constant) & 5.828 & 1.952 & & 2.985 & .004 \\
\hline & EFEKTIVITAS & & & & & \\
\hline & PEMBELAJARAN & 1.043 & .081 & .881 & 12.901 & .000 \\
\hline & DARING & & & & & \\
\hline
\end{tabular}

Coefficients $^{\text {a }}$

a. Dependent Variable: PEMAHAMAN MAHASISWA 
Dari tabel 3 diatas, maka dapat dilihat bahwa hasil uji t hitung untuk variabel Efektivitas Pembalajaran daring adalah sebesar 12.901 dan nilai t tabel sebesar 2.01, yang artinya bahwa $t$ hitung > t tabel ( $12.901>2,01$ ). Dan untuk nilai signifikannya, diperoleh nilai sebesar 0,000, dan hal ini menunjukkan bahwa nilai signifikan $0,000<\alpha=0,05$. Dari penjelasan hasil uji-t tersebut, maka dapat disimpulkan bahwa $\mathrm{HO}$ ditolak dan Ha diterima, dalam arti secara parsial Efektivitas Pembalajaran daring berpengaruh signifikan terhadap pemahaman mahasiswa akuntansi pada mata kuliah auditing.

\section{Uji R(Adjusted $R$ Square)}

Tujuan dari dilakukannya uji $\mathrm{R}$ adalah untuk melihat kemampuan variabel independen dalam menerangkan variabel dependen dan proporsi variasi dari variabel dependen yang diterangkan oleh variasi dari variabel-variabel independennya.

Nilai koefisien determinasi adalah antara 0-1. Jika R2 yang diperoleh dari hasil perhitungan menunjukkan semakin besar mendekati satu, maka dapat dikatakan bahwa sumbangan dari variabel independen terhadap variabel dependen semakin besar.berikut tabel hasil uji $\mathrm{R}$ yang peneliti dapatkan dengan menggunakan SPSS V20:

Tabel 4. Hasil Uji R

Model Summary ${ }^{\mathrm{b}}$

\begin{tabular}{|l|r|r|r|r|r|}
\hline Model & \multicolumn{1}{|c|}{$\mathrm{R}$} & R Square & $\begin{array}{c}\text { Adjusted R } \\
\text { Square }\end{array}$ & $\begin{array}{c}\text { Std. Error of } \\
\text { the Estimate }\end{array}$ & $\begin{array}{c}\text { Durbin- } \\
\text { Watson }\end{array}$ \\
\hline 1 & $.881^{\mathrm{a}}$ & .776 & .771 & 2.771 & 2.227 \\
\hline
\end{tabular}

a. Predictors: (Constant), EFEKTIVITAS PEMBELAJARAN DARING

b. Dependent Variable: PEMAHAMAN MAHASISWA

Berdasarkan tabel 4 diatas, diperoleh nilai R Square sebesar 0,776 dan nilai Adjusted R Square sebesar 0,771, yang menunjukkan bahwa pengaruih Efektivitas Pembalajaran daring terhadap pemahaman mahasiswa akuntansi pada mata kuliah auditing. adalah sebesar 77,1\%, dan sisanya $22,9 \%$ dipengaruhi oleh variabel lain diluar dari variabel yang diteliti oleh peneliti.

\section{KESIMPULAN}

\section{A. Kesimpulan}

Adapun kesimpulan dari hasil penelitian adalah sebagai berikut:

1. Berdasarkan hasil uji thitung untuk variabel Efektivitas Pembalajaran daring adalah sebesar 12.901 dan nilai $\mathrm{t}$ tabel sebesar 2.01, yang artinya bahwa thitung > t tabel $(12.901>2,01)$. Dan untuk nilai signifikannya, diperoleh nilai sebesar 0,000, dan hal ini menunjukkan bahwa nilai signifikan $0,000<\alpha=0,05$.

2. Berdasarkan hasil uji $\mathrm{R}$ diperoleh nilai $\mathrm{R}$ Square sebesar 0,776 dan nilai Adjusted $\mathrm{R}$ Square sebesar 0,771, yang menunjukkan bahwa pengaruih Efektivitas Pembalajaran daring terhadap pemahaman mahasiswa akuntansi pada mata kuliah auditing. adalah sebesar 77,1\%, dan sisanya 22,9\% dipengaruhi oleh variabel lain diluar dari variabel yang diteliti oleh peneliti. 


\section{B. Saran}

Untuk mengakhiri penulisan penelitian ini, penulis akan memberikan beberapa saran sebagai berikut :

1. Bagi pihak dosen untuk lebih memvariasikan metode mngajar dengan media daring agar mahasiswa lebih semangat dan tidak merasa bosan dengan suasana belajar.

2. Semaksimal mungkin menggunakan teknologi dan waktu dalam mengajar selama perkuliahan daring, sehingga penjelasan tentang mata kuliah audit bisa tersampaikan dengan baik

3. Kepada para mahasiswa agar lebih aktif dan kreatif pada saat proses belajar dan mencari tahu secara mandiri mengenaik hal - hal yang tidak dimengerti yang nantiny akemudian bisa diskusikan kepada dosen atau teman-teman sekelas.

\section{DAFTAR PUSTAKA}

[1] Abdullah, Thamrin dan Francis Tantri. 2012. Manajemen Pemasaran Cetakan Pertama. Jakarta : PT. Raja Grafindon Persada.

[2] Agoes, Sukrisno. 2004. Auditing. Jakarta: Lembaga Penerbit Fakultas Ekonomi Universitas Indonesia.

[3] AM, Sardiman (2003). Interaksi dan Motivasi Belajar Mengajar. Jakarta: PT Raja Grafindo Persada.

[4] Anderson, Mrevor dkk. (2004). Ensiklopedia Pengetahuan Populer. Terjemahan oleh Etty Indriati, dan Imam Santoso. 2008. Jakarta: PT Lentera Abadi.

[5] Hery. 2016. Auditing dan Asurans, Jakarta: Grasindo

[6] Hery. 2016. Akuntansi Dasar 1 \& 2. Jakarta: Grasindo.

[7] Jusup, Haryono. 2001. Auditing (Pengauditan). Yogyakarta : STIE YKPN

[8] 2014. Auditing (Pengauditan Berbasis ISA), Edisi 2. Yogyakarta : STIE YKPN.

[9] Mardiasmo. (2005). Akuntansi Sektor Publik. Edisi 2. Yogyakarta: Penerbit Andi

[10] Mulyadi. 2010. Auditing. Edisi Kenam. Buku 1. Jakarta : Salemba Empat.

[11] 2010. Sistem Akuntansi, Edisi ke-3, Cetakan ke-5. Penerbit Salemba Empat, Jakarta.

[12] 2014. Audit 1, Edisi ke-6. Penerbit Salemba Empat, Jakarta

[13] 2014. Audit 2, Edisi ke-6. Penerbit Salemba Empat, Jakarta.

[14] Putria, H., Uwatun , D. A., \& Maula, L. H. (2020). Analisis Proses Pembelajaran Dalam Jaringan (Daring) Masa Pandemi Covid19 Pada Guru Sekolah Dasar. Jurnal Basicedu, 4(4), 861-872. doi:DOI: 10.31004/basicedu.v4i4.460

[15] Rochaman, N. 2005. Aktivitas Belajar. Jakarta: Depdiknas.

[16] Sanjaya, Wina. 2006. Strategi pembelajaran berorientasi standar proses pendidikan. Jakarta: Kencana Prenada Media Group

[17] 2008. Perencanaan dan desain sistem pembelajaran. Jakarta: Kencana Prenada Media Group.

[18] Suryosubroto. 2009. Proses Belajar Mengajar di Sekolah. Jakarta: PT: Rhineka Cipta. https://e-journal.potensi-utama.ac.id/ojs/index.php/Accumulated/ | redaksijurnalupu @ gmail.com 
[19] Sutirman. 2006. Komunikasi Efektif Dalam Pembelajaran. Efisiensi Kajian Ilmu Administrasi, IV(2), 109-121.

[20] Tuanakotta, Theodorus M. 2007. AkuntansiForensik dan Audit Investigatif. Jakarta : Lembaga Penerbit Fakultas Ekonomi Universitas Indonesia. 2010. Akuntansi Forensik dan Audit Investigatif, Edisi 2. Jakarta : Salemba Empat. Salemba Empat. 2014. Audit Berbasis ISA (International Standards on Auditing). Jakarta :

[23] Yusuf , B. B. (2018). Konsep dan Indikator Pembelajaran Efektif. Jurnal Kajian Pembelajaran dan Keilmuan, 1(2), 13-20.

[24] (2017). Konsep danIndikator Pembelajaran Efektif. Jurnal Pembelajaran dan Keilmuan, 1(2), 14-20. Retrieved Maret 1, 2021

[25] Vivi Utari, Ahmad Fauzan \& Media Rosha, Peningkatan Kemampuan Pemahaman Konsep Melalui Pendekatan PMR dalam Pokok Bahasan Prisma dan Limas. Jurnal: Pendidikan Matematika, Vol. 1 No. 1, 2012), h. 34 